\title{
BIOSYNTHESIS OF KETOMYCIN
}

\author{
Yoshio Takeda ${ }^{\dagger}$, Vivien MaK, Chiu-Chin Chang, \\ Ching-Jer Chang and Heinz G. Floss ${ }^{\dagger \dagger}$ \\ Department of Medicinal Chemistry and Pharmacognosy, \\ School of Pharmacy and Pharmacal Sciences, Purdue University, \\ West Lafayette, Indiana 47907, U.S.A.
}

(Received for publication May 7, 1984)

\begin{abstract}
The antibiotic ketomycin is formed from shikimic acid via chorismic acid and prephenic acid. Phenylalanine and 2',5'-dihydrophenylalanine are not intermediates in the biosynthesis. Degradation of ketomycin derived from $\left[1,6-{ }^{14} \mathrm{C}\right]$ shikimic acid showed that prephenic acid is converted into ketomycin with stereospecific discrimination between the two enantiotopic edges of the ring, the pro-S-R edge giving rise to the $\mathrm{C}-2^{\prime}, \mathrm{C}-3^{\prime}$ side of the cyclohexene ring of ketomycin.
\end{abstract}

Ketomycin ( $R$-3-cyclohexenylglyoxylic acid) (I) is an antibiotic metabolite ${ }^{1)}$ of Streptomyces

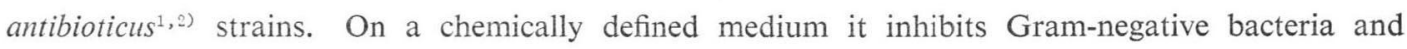
Bacillus subtilis due to its conversion into 3-cyclohexenylglycine, a naturally occurring ${ }^{1,3)}$ false feedback inhibitor of branched chain amino acid biosynthesis ${ }^{2,4}$. In the present communication we report the results of studies on the biosynthesis of ketomycin in S. antibioticus strain Tü 992).

\section{Experimental}

General Methods

Radioactive samples were counted in a Beckman LS7000 or 7500 scintillation counter using Aquasol 2 (Beckman) as solvent. Counting efficiencies were determined for each sample using internal standards of $\left[{ }^{14} \mathrm{C}\right]$ - and $\left[{ }^{3} \mathrm{H}\right]$ toluene. Analytical and semipreparative HPLC was carried out on $\mathrm{C}_{18}$ reverse phase columns on a Waters isocratic system consisting of a M-6000 pump, a UK-6 injector and a R401 refractive index detector. Newly synthesized compounds and intermediates in degradations (non-labeled trial runs) were characterized by their NMR (Varian FT-80 and XL-200 instruments) and mass (DuPont 21-492BR instrument) spectra.

Materials

$\mathrm{D}-\left[U-{ }^{14} \mathrm{C}\right]$ Shikimic acid $(81.1 \mathrm{mCi} / \mathrm{mmol}), \quad \mathrm{L}-\left[U_{-}{ }^{14} \mathrm{C}\right]$ phenylalanine $(486 \mathrm{mCi} / \mathrm{mmol}), \mathrm{D}, \mathrm{L}-\left[3-{ }^{14} \mathrm{C}\right]-$ phenylalanine $(48.0 \mathrm{mCi} / \mathrm{mmol}), \mathrm{D}, \mathrm{L}-\left[1,6-{ }^{14} \mathrm{C}\right]$ shikimic acid $(13.9 \mathrm{mCi} / \mathrm{mmol})$ and $\mathrm{D}-\left[U-{ }^{14} \mathrm{C}\right] \mathrm{glucose}$ were obtained commercially. D,L-2, $5^{\prime}$-Dihydro[3- $\left.{ }^{14} \mathrm{C}\right]$ phenylalanine was prepared in $78 \%$ yield by Birch reduction of D,L-[3-14 C]phenylalanine ${ }^{5)} .\left[G-{ }^{14} \mathrm{C}\right]$ chorismic acid and $\left[G-{ }^{14} \mathrm{C}\right]$ prephenic acid were prepared by biosynthesis from $\left[U-{ }^{14} \mathrm{C}\right]$ glucose using Klebsiella pneumoniae mutant $62-1$ and Salmonella typhimurium mutant Tyr 19, respectively, as described earlier ${ }^{8)}$. Carrier D,L-ketomycin was prepared by L-amino acid oxidase oxidation, in the presence of catalase, of D,L-3-cyclohexenylglycin, which in turn was obtained by STRECKER synthesis ${ }^{7)}$ from 3-cyclohexenealdehyde.

\section{Feeding Experiments}

S. antibioticus strain Tü 992) was obtained from Prof. H. ZäHNER, Tübingen, and was maintained as a spore suspension in $20 \%$ glycerol at $-20^{\circ} \mathrm{C}$. Slants of inoculum were prepared on Emerson agar (BBL, Becton Dickinson and Co.). Seed cultures and production cultures were grown in 500-ml Er-

† Present address: Faculty of Pharmaceutical Sciences, Tokushima University, Tokushima, Japan

t† Present address: Department of Chemistry, The Ohio State University, Columbus, Ohio, 43210, U.S.A. 
lenmeyer flasks containing $100 \mathrm{ml}$ of medium consisting of $2 \% \mathrm{D}$-mannitol and $2 \%$ soy bean meal in tap water. These cultures were incubated at $27^{\circ} \mathrm{C}$ with shaking on a New Brunswick rotary shaker at a speed of $350 \mathrm{rpm}$. Seed cultures were inoculated with a loopful of spore suspension from a slant and grown for 72 hours; each production flask was then inoculated with $10 \mathrm{ml}$ of seed culture and incubated for 48 hours. Labeled precursors were added as Millipore-sterilized solutions to the production cultures 24 hours after inoculation.

The cultures were harvested, Celite 554 ( 2 g per flask) was added and the broth was filtered through two layers of Whatman No. 1 filter paper to remove the mycelium. The volume of the filtrate was reduced to $100 \mathrm{ml}$ under vacuum and the solution was adjusted to $\mathrm{pH} 5$ with $2 \mathrm{~N} \mathrm{HCl}$, filtered and extracted 3 times with EtOAc. The extract was discarded and the aqueous layer adjusted to $\mathrm{pH} 2$ with $2 \mathrm{~N} \mathrm{HCl}$, filtered and extracted 10 times with EtOAc. The extract was dried over sodium sulfate and evaporated to dryness under a vacuum. The residue was subjected to column chromatography ( $50 \mathrm{~g}$ silica gel $60 \sim$ 200 mesh per 1 fermentation broth) with EtOAc $-\mathrm{H}_{2} \mathrm{O}-\mathrm{AcOH}, 40: 12: 1$ (organic phase) as developing solvent. Fractions of $3 \mathrm{ml}$ were collected and the ketomycin-containing fractions, located by TLC in the same system, were pooled and evaporated to dryness. The crude ketomycin was further purified by preparative TLC (silica gel $\mathrm{F}_{254}, 1 \mathrm{~mm}$ thick, solvent as above) eluted with $\mathrm{CHCl}_{3}-\mathrm{MeOH}, 7: 3$ and recrystallized from EtOH. Yields of pure isolated material averaged $30 \sim 50 \mathrm{mg} /$ liter culture broth.

Degradation of I Derived from $\left[U-{ }^{14} \mathrm{C}\right]$ Shikimic Acid

The radioactive I was diluted with carrier $\mathbf{I}$ and rechromatographed to give $102.5 \mathrm{mg}$ product, which was dissolved in a minimal amount of $\mathrm{H}_{2} \mathrm{O}(<2 \mathrm{ml})$. The solution was neutralized with $1 \mathrm{~N}$ $\mathrm{NaOH}$ and concentrated in vacuo. One drop of $\mathrm{HCl}, 185 \mathrm{mg}$-bromophenacyl bromide and $8.5 \mathrm{ml}$ $\mathrm{EtOH}$ were then added and the mixture was refluxed for 2 hours to give, after cooling and addition of $3.5 \mathrm{ml} \mathrm{H}_{2} \mathrm{O}, 411 \mathrm{mg}$ ketomycin $p$-bromophenacyl ester. This material was recrystallized repeatedly from dilute $\mathrm{EtOH}$ until the specific radioactivity was constant. Ketomycin was then regenerated from the ester by hydrolysis with $1 \mathrm{~N} \mathrm{NaOH}$ (17 hours room temp), extraction from the acidified solution with EtOAc and preparative layer chromatography (silica gel, EtOAc $-\mathrm{H}_{2} \mathrm{O}-\mathrm{HCOOH}, 40: 12: 1$, organic phase).

The $\left[{ }^{14} \mathrm{C}\right]$ ketomycin $\left(140.3 \mathrm{mg}\right.$ ) was dissolved in $3 \mathrm{ml} \mathrm{40} \% \mathrm{NaOH}$, and $5 \mathrm{ml} \mathrm{15 \%} \mathrm{H}_{2} \mathrm{O}_{2}$ was added dropwise with ice cooling. After stirring at room temperature for 24 hours, the reaction mixture was acidified with conc $\mathrm{HCl}$ and extracted with $3 \times 15 \mathrm{ml} \mathrm{CHCl}_{3}$. The extract was dried $\left(\mathrm{Na}_{2} \mathrm{SO}_{4}\right)$, concentrated in vacuo, and filtered through a silica gel column $(1 \times 15 \mathrm{~cm})$. The first $30 \mathrm{ml}$ eluate were collected and evaporated to give $64.9 \mathrm{mg} 3$-cyclohexenecarboxylic acid as an oil. A small aliquot was converted to the $p$-bromophenacyl ester for radioactivity measurement.

3-Cyclohexenecarboxylic acid (112.5 mg, diluted 2.6 fold from previous step) was dissolved in $10 \mathrm{ml} \mathrm{MeOH}$ and hydrogenated over $\mathrm{PtO}_{2}(5 \mathrm{mg})$ for 4.5 hours at room temperature and atmospheric pressure. The catalyst was filtered off, the solution evaporated and the residue dried in a desiccator over $\mathrm{P}_{2} \mathrm{O}_{5}$. The residue of $52.8 \mathrm{mg}$ cyclohexanecarboxylic acid was then dissolved in $1.5 \mathrm{ml} 100 \%$ $\mathrm{H}_{2} \mathrm{SO}_{4}$ (3 parts conc $\mathrm{H}_{2} \mathrm{SO}_{4}+1$ part fuming $\mathrm{H}_{2} \mathrm{SO}_{4}$ ) and $100 \mathrm{mg} \mathrm{NaN}$ was added. The reaction was heated to $60^{\circ} \mathrm{C}$ for 2 hours while the $\mathrm{CO}_{2}$ generated was flushed with a gentle stream of $\mathrm{N}_{2}$ (passed successively through wash bottles containing $2 \mathrm{~N} \mathrm{Ba}(\mathrm{OH})_{2}$ solution and conc $\mathrm{H}_{2} \mathrm{SO}_{4}$ ) via a wash bottle with $\mathrm{KMnO}_{4}$ solution in $2 \mathrm{~N} \mathrm{H}_{2} \mathrm{SO}_{4}$ into a trap containing $0.2 \mathrm{~N} \mathrm{Ba}(\mathrm{OH})_{2}$ solution. The latter was protected from atmospheric $\mathrm{CO}_{2}$ by a second trap also containing $0.2 \mathrm{~N} \mathrm{Ba}(\mathrm{OH})_{2}$. The resulting $\mathrm{BaCO}_{3}$ was collected by filtration, washed with $\mathrm{H}_{2} \mathrm{O}, \mathrm{EtOH}$ and ether, dried $(11.6 \mathrm{mg})$ and dissolved in 1.5 $\mathrm{ml} 0.05 \mathrm{~m}$ EDTA solution for radioactivity analysis. The reaction mixture was made alkaline and steam distilled $(300 \mathrm{ml})$ into $100 \mathrm{ml} 2 \mathrm{~N} \mathrm{HCl}$. The aqueous distillate was evaporated to dryness and the residue benzoylated $(0.5 \mathrm{ml}$ benzoylchloride in $3 \mathrm{ml}$ pyridine). The product was purified by preparative layer chromatography (silica gel, benzene - ether, 9:1, developed twice) to give, after recrystallization from ether, $8.3 \mathrm{mg} N$-benzoylcyclohexylamine.

\section{Degradation of I Derived from $\left[1,6-{ }^{-14} \mathrm{C}\right]$ Shikimic Acid}

Methyl 3-Cyclohexenecarboxylate: Ketomycin $(98.89 \mathrm{mg})$ was oxidized to 3-cyclohexenecarbo- 
xylic acid in $80 \%$ yield as described above. To the product was added non-labeled 3 -cyclohexenecarboxylic acid (6.2:1). To a solution of the diluted material $(447.2 \mathrm{mg})$ in $3 \mathrm{ml}$ ether was added dropwise with stirring a solution of diazomethane in ether until a yellow color persisted. After standing for another hour, excess diazomethane was destroyed with a few drops of formic acid. The ether solution was washed with $\mathrm{H}_{2} \mathrm{O}$, saturated sodium bicarbonate solution, $\mathrm{H}_{2} \mathrm{O}$ and saturated sodium chloride solution. After drying over magnesium sulfate the ether was evaporated to give the methyl ester in $92 \%$ yield.

Diphenyl-3-cyclohexenylcarbinol: To a solution of methyl 3-cyclohexenecarboxylate $(457 \mathrm{mg})$ in dry ether stirred at $0^{\circ} \mathrm{C}$ under an argon atmosphere was added by syringe a solution of phenyllithium $(5.2 \mathrm{ml}, 9.8 \mathrm{~mm})$ in cyclohexane - ether, $7: 3$. After 10 minutes the temperature was raised to ambient and after another hour the mixture was heated to reflux overnight. The reaction mixture was then cooled to room temperature and hydrolyzed by addition of $25 \mathrm{ml} \mathrm{H}_{2} \mathrm{O}$. The ether phase was separated and the aqueous layer extracted 3 more times with ether. The combined ether extract was washed with $\mathrm{H}_{2} \mathrm{O}$ and saturated sodium chloride solution and dried over magnesium sulfate. The yellow oil obtained upon evaporation of the solvent was purified by preparative layer chromatography (silica gel Sil-100 $\mathrm{UV}_{254}, 1 \mathrm{~mm}$ thick, hexane as solvent) to give the product in $90 \%$ yield.

Diphenylmethylene-3-cyclohexene: The tertiary alcohol obtained in the previous step $(726 \mathrm{mg})$ was dissovled in $5 \mathrm{ml}$ dry $\mathrm{Me}_{2} \mathrm{CO}$. Conc $\mathrm{H}_{2} \mathrm{SO}_{4}$ ( $1 \mathrm{ml}$ per $1.15 \mathrm{mmol}$ reactant) was added dropwise at room temperature to the stirred solution, which turned orange-brown in color. $\mathrm{H}_{2} \mathrm{O}$ was then added and the $\mathrm{Me}_{2} \mathrm{CO}$ was removed in a vacuum. The aqueous solution was extracted 4 times with $\mathrm{CHCl}_{3}$ and the extract was dried and evaporated to dryness. The brownish residue was purified by preparative layer chromatography (silica gel Sil-100 $\mathrm{UV}_{254}, 1 \mathrm{~mm}$ thick, hexane) to give the product in $55 \%$ yield.

Succinic Acid: The olefin from the previous step $(350 \mathrm{mg}$ ) was dissolved in pyridine and added dropwise with stirring to a solution of $3.2 \mathrm{~g} \mathrm{KMnO}_{4}$ and $20.8 \mathrm{~g} \mathrm{NaIO}_{4}$ in $30 \mathrm{ml}_{1} \mathrm{~N} \mathrm{H}_{2} \mathrm{SO}_{4}$. The mixture eventually turned dark brown with heat and gas evolution and was allowed to stand until it had returned to room temperature. It was filtered and the precipitate washed several times with $\mathrm{H}_{2} \mathrm{O}$. The combined filtrates were acidified to $\mathrm{pH} 2$ with $6 \mathrm{~N} \mathrm{H}_{2} \mathrm{SO}_{4}$ and extracted continuously with ether overnight. The ether extract was evaporated to dryness, the residue redissolved in $20 \mathrm{ml} \mathrm{H}_{2} \mathrm{O}$ and adjusted to $\mathrm{pH} 10$ with $6 \mathrm{~N} \mathrm{NaOH}$. This solution was washed several times with ether, then brought to $\mathrm{pH} 2$ and again extracted continuously with ether overnight. This ether extract was then evaporated and the residue dissolved in $5 \mathrm{ml} 0.01 \%$ trifluoroacetic acid. The succinic acid was purified by semipreparative HPLC on an Alltech $5 \mu \mathrm{C}_{18}$ column with $0.01 \%$ trifluoroacetic acid $(\mathrm{pH} 2)$ as solvent at $0.8 \mathrm{ml} /$ minute flow rate (retention time $11 \sim 12$ minutes). The collected fractions containing the product were lyophilized to give $22.56 \mathrm{mg}$ pure succinic acid. For the determination of its specific radioactivity, the succinic acid was quantitated both by weight and by HPLC (refractive index detector response) against a standard curve.

\section{Results}

Inspection of the structure of ketomycin suggests a biosynthetic origin from shikimic acid. This was confirmed by feeding D-[U- $\left.{ }^{14} \mathrm{C}\right]$ shikimic acid to 24 -hour old cultures of S. antibioticus strain Tü 99. I was isolated from the cultures 24 hours later and purified to constant specific radioactivity. The results (Table 1, Expts 1 and 2), 1.64 and 2.87\% incorporation, indicate an effective precursor role of shikimic acid in $\mathbf{I}$ biosynthesis.

Shikimic acid could be converted to I by two principally different pathways. One would involve utilization of all 7 carbon atoms of the precursor and extension of the side chain by one additional carbon atom $\left(\mathrm{C}_{6} \mathrm{C}_{1}+\mathrm{C}_{1}\right)$. As an alternative, only the 6 ring carbon atoms of shikimic acid might be utilized to generate, via chorismic acid and prephenic acid, a $\mathrm{C}_{6} \mathrm{C}_{3}$ compound which would undergo shortening of the side chain by one carbon atom $\left(\mathrm{C}_{6} \mathrm{C}_{3}-\mathrm{C}_{1}\right)$. To determine whether only 6 or all 7 
Table 1. Incorporation of labeled precursors into ketomycin by S. antibioticus Tü 99 .

\begin{tabular}{|c|c|c|c|c|c|c|c|c|c|}
\hline \multirow[b]{2}{*}{$\begin{array}{l}\text { Expt } \\
\text { No. }\end{array}$} & \multicolumn{4}{|c|}{ Precursor fed } & \multicolumn{3}{|c|}{ Ketomycin isolated } & \multirow[b]{2}{*}{$\begin{array}{l}\text { Incorpora- } \\
\text { tion rate } \\
(\%)\end{array}$} & \multirow[b]{2}{*}{$\begin{array}{l}\text { Dilution } \\
\text { factor }\end{array}$} \\
\hline & Compound & $\begin{array}{c}\text { Specific } \\
\text { radioactivity } \\
(\mathrm{dpm} / \mathrm{mmol})\end{array}$ & $\underset{(\mu \mathrm{mol})}{\text { Amount }}$ & $\begin{array}{l}\text { Radio- } \\
\text { activity } \\
(\mathrm{dpm})\end{array}$ & $\begin{array}{l}\text { Amount } \\
(\mu \mathrm{mol})\end{array}$ & $\begin{array}{l}\text { Radio- } \\
\text { activity }^{\mathrm{a}} \\
(\mathrm{dpm})\end{array}$ & $\begin{array}{c}\text { Specific } \\
\text { radioactivity } \\
(\mathrm{dpm} / \mathrm{mmol})\end{array}$ & & \\
\hline 1 & $\mathrm{D}-\left[U_{-}{ }^{14} \mathrm{C}\right]$ Shikimic acid & $7.1 \times 10^{8}$ & 29.7 & $2.10 \times 10^{7}$ & 1.35 & $6.0 \times 10^{5}$ & $4.5 \times 10^{5}$ & 2.87 & 1,580 \\
\hline 2 & $\mathrm{D}-\left[U-{ }^{14} \mathrm{C}\right]$ Shikimic acid & $1.18 \times 10^{8}$ & 213 & $2.51 \times 10^{7}$ & 245 & $4.1 \times 10^{5}$ & $1.68 \times 10^{6}$ & 1.64 & 70 \\
\hline 3 & $\mathrm{~L}-\left[U-{ }^{14} \mathrm{C}\right]$ Phenylalanine & $1.10 \times 10^{12}$ & 0.04 & $3.85 \times 10^{7}$ & 200 & $4 \times 10^{3}$ & $1.91 \times 10^{4}$ & 0.01 & - \\
\hline 4 & {$\left[G-{ }^{14} \mathrm{C}\right]$ Chorismic acid } & $3.56 \times 10^{7}$ & 239 & $8.5 \times 10^{6}$ & 95 & $2.0 \times 10^{4}$ & $2.1 \times 10^{5}$ & 0.24 & 177 \\
\hline 5 & {$\left[G-{ }^{14} \mathrm{C}\right]$ Prephenic acid } & $3.59 \times 10^{7}$ & 454 & $1.63 \times 10^{7}$ & 804 & $5.4 \times 10^{4}$ & $6.7 \times 10^{4}$ & 0.33 & 536 \\
\hline 6 & $\mathrm{D}, \mathrm{L}-\left[1,6-{ }^{14} \mathrm{C}\right]$ Shikimic acid & $1.52 \times 10^{8}$ & $730^{\mathrm{b}}$ & $1.11 \times 10^{8 \mathrm{~b}}$ & 411 & $1.88 \times 10^{8}$ & $4.57 \times 10^{6}$ & 1.69 & 33 \\
\hline 7 & $\mathrm{D}, \mathrm{L}-\left[1,6-{ }^{14} \mathrm{C}\right]$ Shikimic acid & $3.06 \times 10^{10}$ & 3.3 & $1.21 \times 10^{8}$ & 648 & $2.04 \times 10^{8}$ & $3.15 \times 10^{6}$ & $3.37^{\circ}$ & - \\
\hline 8 & $\begin{array}{l}\mathrm{D}, \mathrm{L}-2^{\prime}, 5^{\prime} \text {-Dihydro- } \\
{\left[3-{ }^{14} \mathrm{C}\right] \text { phenylalanine }}\end{array}$ & $1.27 \times 10^{9}$ & 51 & $6.5 \times 10^{7}$ & 43.3 & $5.59 \times 10^{4}$ & $1.29 \times 10^{5}$ & 0.086 & 9,845 \\
\hline 9 & $\mathrm{D}, \mathrm{L}-\left[1,6-{ }^{14} \mathrm{C}\right]$ Shikimic acid & $3.06 \times 10^{10}$ & 79.2 & $2.42 \times 10^{8}$ & 135 & $4.1 \times 10^{6}$ & $3.05 \times 10^{6}$ & 1.71 & - \\
\hline 10 & $\begin{array}{l}\mathrm{D}, \mathrm{L}-2^{\prime}, 5^{\prime} \text {-Dihydro- }\left[3-{ }^{14} \mathrm{C}\right]- \\
\text { phenylalanine }\end{array}$ & $1.27 \times 10^{9}$ & 20.75 & $2.64 \times 10^{7}$ & 127 & $5.1 \times 10^{3}$ & $4.02 \times 10^{4}$ & 0.02 & - \\
\hline
\end{tabular}

Minimum values based on isolated ketomycin; not corrected for losses during isolation.

b D-Isomer only. The labeled material was diluted with unlabeled D-shikimic acid.

c Based on D-isomer only. 
Fig. 1. Degradation of ketomycin derived from $\mathrm{D}-\left[U_{-}{ }^{14} \mathrm{C}\right]$ shikimic acid.
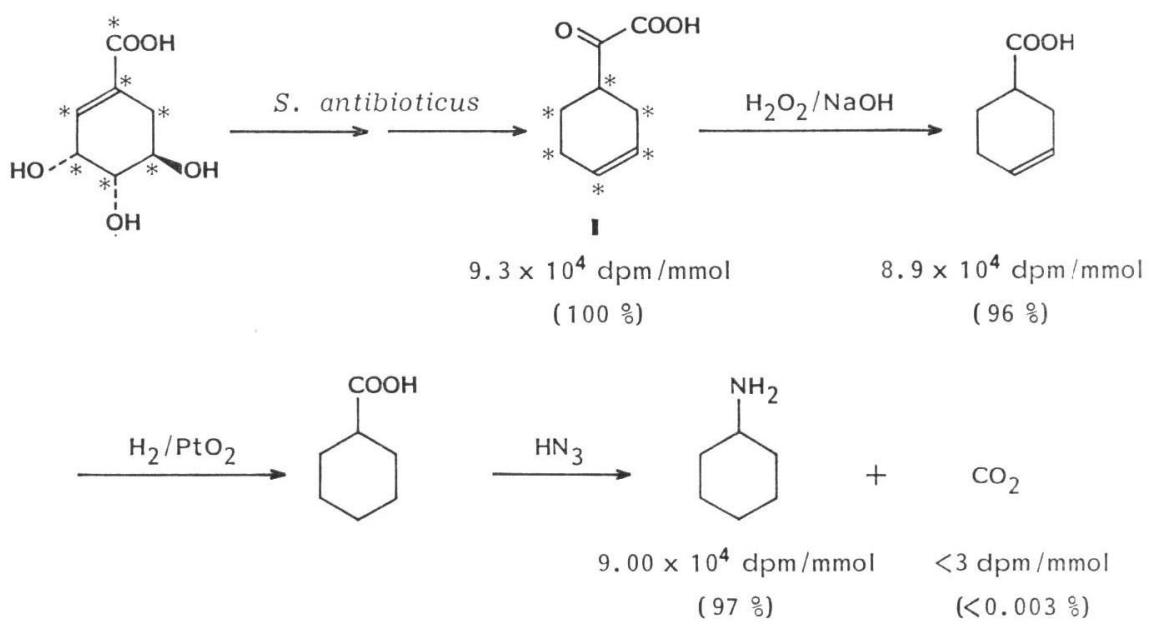

of the carbon atoms of shikimic acid are utilized, a sample of I biosynthesized from D- $\left[U-{ }^{14} \mathrm{C}\right]$ shikimic acid was degraded as shown in Fig. 1 to give cyclohexanecarboxylic acid, which was then subjected to the ScHmid reaction. The results clearly show that only the ring portion of $\mathbf{I}$ is labeled; the $\mathrm{CO}_{2}$ arising from $\mathrm{C}-2$ of the side chain carries no radioactivity. Hence, a $\mathrm{C}_{6} \mathrm{C}_{1}+\mathrm{C}_{1}$ pathway is clearly ruled out.

To probe further the nature of the $\mathrm{C}_{8} \mathrm{C}_{3}$ compound giving rise to $\mathrm{I}$, we fed $\mathrm{L}-\left[U_{-}{ }^{14} \mathrm{C}\right]$ phenylalanine (Table 1, Expt 3). Not surprisingly, the incorporation was very low, indicating that the cyclohexene moiety does not arise by reduction of an aromatic system. To test the precursor role of chorismic acid and prephenic acid, labeled samples of these two compounds were prepared by biosynthesis from $\mathrm{D}-\left[U \mathrm{U}^{14} \mathrm{C}\right]$ glucose using appropriately blocked mutants of $K$. pneumoniae ${ }^{8)}$ and S. typhimurium ${ }^{9)}$. Feeding experiments with these two compounds gave samples of $\mathbf{I}$ containing appreciable amounts of radioactivity (Table 1, Expts 4 and 5). The incorporation rates for chorismic acid and prephenic acid are of the same magnitude, and although they are lower than those of shikimic acid they strongly implicate both compounds in the biosynthetic pathway leading to I. The better incorporation of shikimic acid may reflect differences in permeability or may be due to the greater chemical stability of shikimic acid compared to chorismic acid and prephenic acid.

The involvement of prephenic acid in the biosynthesis of $\mathbf{I}$ raises an interesting stereochemical question. Both in the precursor, shikimic acid, and in the product, ketomycin, the six-membered ring is asymmetric, i.e., the two "sides" C-1, C-2, C-3, C-4 and C-1, C-6, C-5, C-4 of the ring are constitutionally different, whereas prephenic acid has a plane of symmetry bisecting $\mathrm{C}-1$ and $\mathrm{C}-4$ of the ring. However, the two "sides" of the prephenic acid ring are enantiotopic and should thus be distinguishable to a chiral reagent like an enzyme. Asymmetric processing of the ring of prephenic acid has been demonstrated in the biosynthesis of 2,5-dihydrophenylalanine ${ }^{8)}$. To determine if the same is true in the formation of $\mathbf{I}$, and if so, what the orientation of the process is, we fed $\mathrm{D}, \mathrm{L}-\left[1,6-{ }^{14} \mathrm{C}\right] \mathrm{shikimic}$ acid. The resulting samples of I (Table 1, Expts 6 and 7) were subjected to the degradation procedure shown in Fig. 2. Oxidation of $\mathbf{I}$ to 3-cyclohexenecarboxylic acid followed by conversion of the carboxyl group into a diphenylmethylene function set the stage for an oxidative cleavage of the molecule which produced succinic acid from only one side of the ring, namely carbons $1^{\prime}, 4^{\prime}, 5^{\prime}$ and $6^{\prime}$. D- $-\left[1,6-{ }^{14} \mathrm{C}\right]$ Shikimic acid labels chorismic acid and prephenic acid as shown in Fig. 3. The latter contains ${ }^{14} \mathrm{C}$ at $\mathrm{C}-1$ and at 
Fig. 2. Asymmetric degradation of the ring of ketomycin.<smiles>O=C(O)C(=O)C1CCCCC1</smiles>

I<smiles>OC(c1ccccc1)(c1ccccc1)C1CC=CCC1</smiles>

IV

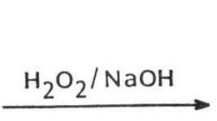<smiles>O=C(O)C1CCCCC1</smiles>

II<smiles>O=S(=O)(O)C1=C(c2ccccc2)CCC=C1</smiles>

V<smiles>CC(=O)C1CC2CCC(C2)C1</smiles>

III

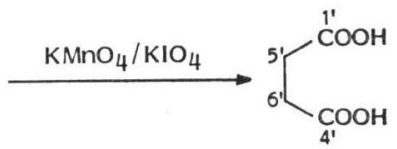

VI

Fig. 3. Pathway of ketomycin biosynthesis (route $a$ represents the observed steric course).

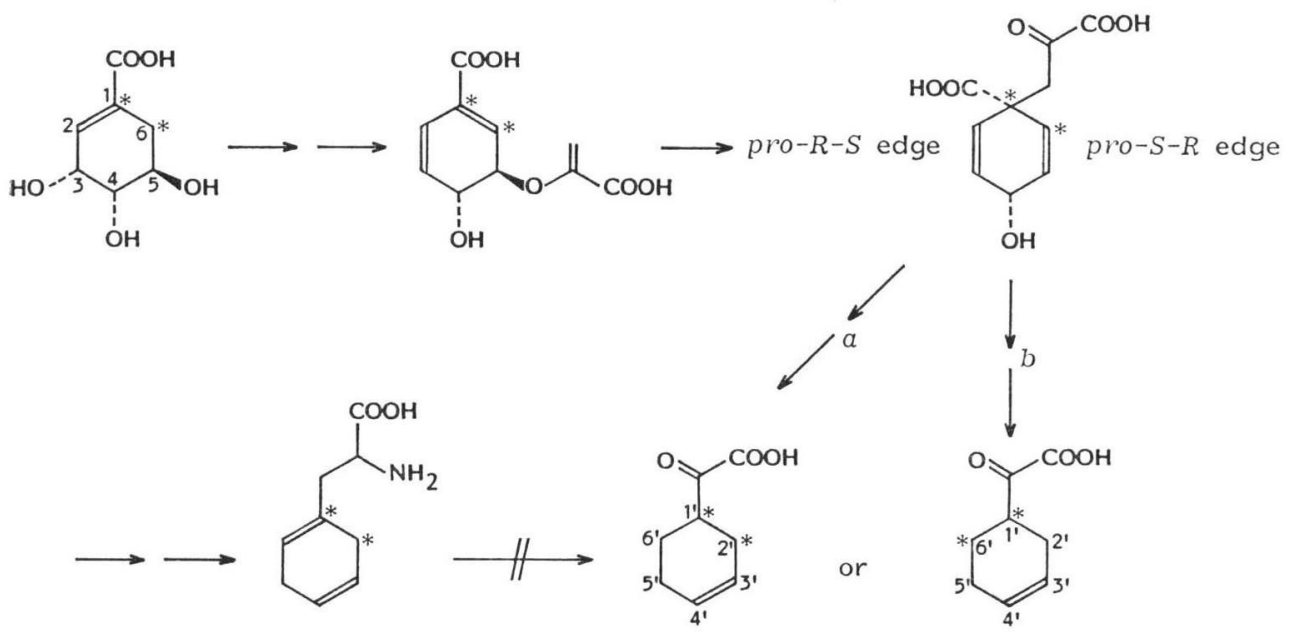

Table 2. Results of the asymmetric degradation of ketomycin biosynthesized from $\mathrm{D}, \mathrm{L}-\left[1,6{ }^{14} \mathrm{C}\right] \mathrm{shikimic}$ acid.

\begin{tabular}{|c|c|c|c|c|}
\hline \multirow[b]{2}{*}{ Compound analyzed } & \multicolumn{2}{|c|}{ 1st degradation } & \multicolumn{2}{|c|}{ 2nd degradation } \\
\hline & $\begin{array}{c}\text { Specific } \\
\text { radioactivity } \\
(\mathrm{dpm} / \mathrm{mmol})\end{array}$ & $\%$ of $\mathbf{I I}^{\mathrm{a}}$ & $\begin{array}{c}\text { Specific } \\
\text { radioactivity } \\
(\mathrm{dpm} / \mathrm{mmol})\end{array}$ & $\%$ of $\mathrm{II}^{\mathrm{a}}$ \\
\hline Ketomycin (I) & $2.90 \times 10^{8}$ & 98 & $1.98 \times 10^{6}$ & 105 \\
\hline 3-Cyclohexenecarboxylic acid (II) & $\begin{array}{l}2.97 \times 10^{6} \text {, diluted } \\
\text { to } 4.11 \times 10^{5}\end{array}$ & $\underline{100}$ & $\begin{array}{l}1.88 \times 10^{8} \text {, diluted } \\
\text { to } 3.78 \times 10^{4}\end{array}$ & $\underline{100}$ \\
\hline $\begin{array}{l}\text { Methyl 3-cyclohexene- } \\
\text { carboxylate (III) }\end{array}$ & $4.18 \times 10^{5}$ & 102 & $3.81 \times 10^{4}$ & 101 \\
\hline Carbinol IV & $3.78 \times 10^{5}$ & 92 & $3.87 \times 10^{4}$ & 102 \\
\hline Olefin V & $3.70 \times 10^{5}$ & 90 & - & - \\
\hline Succinic acid (VI) & $2.08 \times 10^{5}$ & 51 & $1.72 \times 10^{4}$ & 46 \\
\hline
\end{tabular}

a Percentage figures are related to the specific radioactivity of II after dilution, to minimize the effect of any systematic errors at the dilution stage. 
the adjacent carbon in the pro-S-R edge of the ring; this follows from the configuration of chorismic acid and the relative stereochemistry of prephenic acid. Depending on the stereochemical pathway by which prephenic acid is processed, I will be labeled either in the $1^{\prime}, 2^{\prime}$ or in the $1^{\prime}, 6^{\prime}$ positions. The succinic acid resulting from the degradation of I should contain either $50 \%$ (pathway a) or $100 \%$ (pathway $b$ ) of the radioactivity of $\mathbf{I}$. If the processing of prephenic acid were non-stereospecific with respect to the two enantiotopic sides of the ring, the succinic acid should contain $75 \%$ of the label. The results (Table 2) of two independent experiments show rather clearly and in good agreement that the succinic acid contains half the label of the ketomycin from which it was derived. The processing of prephenic acid in the formation of $\mathbf{I}$ therefore is stereospecific and occurs along pathway $a$ (Fig. 3).

The above results demonstrate that a biosynthetic pathway must operate in S. antibioticus which converts prephenate, an immediate precursor of a benzene ring, into a hydroaromatic six-membered carbocyclic ring. A similar situation exists in the biosynthesis of $2^{\prime}, 5^{\prime}$-dihydrophenylalanine ${ }^{6)}$, an ubiquitous Streptomyces metabolite ${ }^{10 \sim 18)}$. It therefore seemed a plausible possibility that dihydrophenylalanine or the corresponding keto acid, might be an intermediate in the biosynthesis of $\mathbf{I}$. The labeling pattern of the two compounds from $\left[1,6-{ }^{14} \mathrm{C}\right]$ shikimic acid (Fig. 3) would be compatible with formation of the $\Delta^{3}$-cyclohexene ring of $\mathbf{I}$ by reduction of the $\Delta^{1}$ double bond in the ring of dihydrophenylalanine. To test this hypothesis we prepared $\mathrm{L}-2^{\prime}, 5^{\prime}$-dihydro $\left[3-{ }^{14} \mathrm{C}\right]$ phenylalanine by BIRCH reduction of $\mathrm{L}-\left[3-{ }^{14} \mathrm{C}\right]$ phenylalanine ${ }^{5)}$ and fed it to cultures of $S$. antibioticus. The high dilution factor and the low incorporation rate into I (Table 1, Expt 8) leave little doubt that L-dihydrophenylalanine is not an intermediate in the biosynthesis of $\mathbf{I}$. This result was confirmed in a second set of experiments in which $\mathrm{L}-2^{\prime}, 5^{\prime}$-dihydro[ $\left[3-{ }^{14} \mathrm{C}\right]$ phenylalanine and $\mathrm{D}, \mathrm{L}-\left[1,6-{ }^{14} \mathrm{C}\right]$ shikimic acid were fed to parallel cultures (Table 1, Expts 9 and 10). Again, dihydrophenylalanine was incorporated very poorly, whereas shikimic acid was used very efficiently.

\section{Discussion}

The results of this study show that ketomycin is formed in S. antibioticus from shikimic acid via chorismic acid and prephenic acid, i.e., only the six ring carbon atoms of shikimic acid are utilized in the formation of $\mathbf{I}$. Prephenic acid is converted into I stereospecifically, the pro- $S$ - $R$ edge of the ring giving rise to carbon atoms $1^{\prime}, 2^{\prime}, 3^{\prime}, 4^{\prime}$ of the cyclohexene ring. These findings completely parallel the observations made earlier ${ }^{8)}$ about the biosynthesis of dihydrophenylalanine. It was therefore surprising to find that dihydrophenylalanine is not a precursor of $\mathbf{I}$; one would expect that a pathway already widespread in Streptomyces would be utilized to elaborate the ring system of $\mathbf{I}$.

The pathway of ketomycin formation, to the extent it has been established by these studies, is summarized in Fig. 3. The transformation of prephenic acid into I seems to represent yet another new variant of the shikimate pathway. It may occur by only a minor variation of the route leading to dihydrophenylalanine, i.e., modification of the 3-carbon side chain before the ring is converted into the $\Delta^{1,4}$-cyclohexadiene and then into the $\Delta^{3}$-cyclohexene system. Alternatively, the cyclohexadienol system of prephenic acid may be converted into the cyclohexene ring of $\mathbf{I}$ in a completely different way, e.g., in a reaction sequence initiated by reduction of the two double bonds. More experiments are obviously needed to delineate the sequence of reactions leading from prephenic acid to ketomycin.

\section{Acknowledgments}

We are indebted to Prof. H. ZäHNER, Tübingen, for providing a cluture of S. antibioticus Tü 99, and to Dr. G.-U. BILLINGER, who carried out some of the initial experiments on ketomycin biosynthesis. Financial support of this work by the National Institutes of Health through research grants AI 11728 and AI 20264 is gratefully acknowledged. 


\section{References}

1) Celmer, W. D.: Substituted 3-cyclohexene antibiotics. Belg, Pat. 644,682, Sept. 4, 1964; Chem. Abstr. 63: 9836a, 1965

2) Keller-Schierlein, W.; K. Poralla \& H. Zähner: Stoffwechselprodukte von Mikroorganismen. 78. Isolierung, Identifizierung und Wirkungsweise von Ketomycin $((R)-3$-Cyclohexenylglyoxylsäure) und dessen Umwandlungsprodukt 3-Cyclohexenylglycin. Arch. Mikrobiol. 67: 339 356, 1969

3) KöNIG, W. A.; H. HAGEmeIER \& U. DäHN: Stoffwechselprodukte von Mikroorganismen. $146 . \quad$ Massenspektrometrische Identifizierung von 3-Cyclohexenylglycin im Kulturfiltrat von Streptomyces tendae. Z. Naturforschg. 30b: 626 628, 1975

4) JACKSON, J. H. \& H. E. Umbarger: Defective transamination, a mechanism for resistance to ketomycin in Escherichia coli. Antimicrob. Agents Chemother. 3: 510 516, 1973

5) Snow, M. L.; C. Laurnger \& C. Ressler: 1,4-Cyclohexadiene-1-alanine (2,5-dihydrophenylalanine), a new inhibitor of phenylalanine for the rat and Leuconostoc dextranicum 8086. J. Org. Chem. 33: 1774 1780,1968

6) Shimada, K.; D. J. Hook, G. F. Warner \& H. G. Floss: Biosynthesis of the antibiotic 2,5-dihydrophenylalanine by Streptomyces arenae. Biochemistry 17: 3054 3058, 1978

7) Edelson, J.; J. D. Fissekis, C. G. Skinner \& W. Shive: 3-Cyclohexene-1-glycine, an isoleucine antagonist. J. Am. Chem. Soc. 80: 2698 2700, 1958

8) Gibson, F.: Preparation of chorismic acid. Methods Enzymol. 17A: 362 364, 1970

9) Dayan, J. \& D. B. Sprinson: Preparation of prephenic acid. Methods Enzymol. 17A: 559 561, 1970

10) Scannell, J. P.; D. L. Pruess, T. C. Demny, T. Williams \& A. Stempel: L-3-(2,5-Dihydrophenyl)alanine, an antimetabolite of L-phenylalanine produced by a streptomycete. J. Antibiotics 23: 618 619, 1970

11) Yamashita, T.; N. Miyairi, K. Kunugita, K. Shimizu \& H. Sakai: L-1,4-Cyclohexadiene-1-alanine, an antagonist of phenylalanine from Streptomyces. J. Antibiotics 23: 537 541, 1970

12) Fickenscher, U.; W. Keller-Schierlein \& H. ZäHner: Stoffwechselprodukte von Mikroorganismen. 87. L-2,5-Dihydrophenylalanine. Arch. Mikrobiol. 75: 346 352, 1971

13) OKabayashi, K.; H. Morishima, M. Hamada, T. Takeuchi \& H. Umezawa: A tryptophan hydroxylase inhibitor produced by a streptomycete: 2,5-Dihydro-L-phenylalanine. J. Antibiotics 30: 675 677, 1977 